\title{
Article \\ Model Amphipathic Peptide Coupled with Tacrine to Improve Its Antiproliferative Activity
}

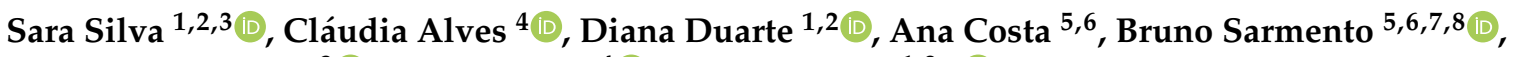 \\ António J. Almeida ${ }^{3}\left(\right.$ D) , Paula Gomes ${ }^{4}(\mathbb{D})$ and Nuno Vale ${ }^{1,9, *(D)}$
}

1 OncoPharma Research Group, Center for Health Technology and Services Research (CINTESIS), Rua Dr. Plácido da Costa, 4200-450 Porto, Portugal; saracpsilva21@gmail.com (S.S.); dianaduarte29@gmail.com (D.D.)

2 Faculty of Pharmacy, University of Porto, Rua de Jorge Viterbo Ferreira, 228, 4050-313 Porto, Portugal

3 Research Institute for Medicines (iMed.ULisboa), Faculty of Pharmacy, Universidade de Lisboa, Avenida Professor Gama Pinto, 1649-003 Lisboa, Portugal; aalmeida@ff.ulisboa.pt

4 Laboratório Associado para a Química Verde (LAQV), Network of Chemistry and Technology (REQUIMTE), Departamento de Química e Bioquímica, Faculdade de Ciências, Universidade do Porto, Rua do Campo Alegre, 687, 4169-007 Porto, Portugal; claudialves05@gmail.com (C.A.); pgomes@fc.up.pt (P.G.)

5 Instituto de Engenharia Biomédica (INEB), University of Porto, Rua Alfredo Allen, 208, 4200-135 Porto, Portugal; ana.margarida.costa@ineb.up.pt (A.C.); bruno.sarmento@ineb.up.pt (B.S.)

6 Instituto de Investigação e Inovação em Saúde (i3S), University of Porto, Rua Alfredo Allen, 208, 4200-135 Porto, Portugal

7 Instituto de Investigação e Formação Avançada em Ciências e Tecnologias da Saúde \& Instituto Universitário de Ciências da Saúde (CESPU), Rua Central de Gandra, 1317, 4585-116 Gandra, Portugal

8 School of Pharmacy, Queen's University Belfast, Medical Biology Centre, 97 Lisburn Rd, Belfast BT9 7BL, UK

9 Faculty of Medicine, University of Porto, Al. Prof. Hernâni Monteiro, 4200-319 Porto, Portugal

* Correspondence: nunovale@med.up.pt; Tel.: +351-225513622

check for updates

Citation: Silva, S.; Alves, C.; Duarte, D.; Costa, A.; Sarmento, B.; Almeida, A.J.; Gomes, P.; Vale, N. Model Amphipathic Peptide Coupled with Tacrine to Improve Its

Antiproliferative Activity. Int. J. Mol. Sci. 2021, 22, 242. https://doi.org/ $10.3390 /$ ijms 22010242

Received: 8 December 2020

Accepted: 22 December 2020

Published: 29 December 2020

Publisher's Note: MDPI stays neutral with regard to jurisdictional claims in published maps and institutional affiliations.

Copyright: () 2020 by the authors. Licensee MDPI, Basel, Switzerland. This article is an open access article distributed under the terms and conditions of the Creative Commons Attribution (CC BY) license (https: / / creativecommons.org/ licenses/by/4.0/).

\begin{abstract}
Drug repurposing and drug combination are two strategies that have been widely used to overcome the traditional development of new anticancer drugs. Several FDA-approved drugs for other indications have been tested and have demonstrated beneficial anticancer effects. In this connection, our research group recently reported that Tacrine, used to treat Alzheimer's Disease, inhibits the growth of breast cancer MCF-7 cells both alone and in combination with a reference drug. In this view, we have now coupled Tacrine with the model amphipathic cell-penetrating peptide (CPP) MAP, to ascertain whether coupling of the CPP might enhance the drug's antiproliferative properties. To this end, we synthesized MAP through solid-phase peptide synthesis, coupled it with Tacrine, and made a comparative evaluation of the parent drug, peptide, and the conjugate regarding their permeability across the blood-brain barrier (BBB), ability to inhibit acetylcholinesterase (AChE) in vitro, and antiproliferative activity on cancer cells. Both MAP and its Tacrine conjugate were highly toxic to MCF-7 and SH-SY5Y cells. In turn, BBB-permeability studies were inconclusive, and conjugation to the CPP led to a considerable loss of Tacrine function as an AChE inhibitor. Nonetheless, this work reinforces the potential of repurposing Tacrine for cancer and enhances the antiproliferative activity of this drug through its conjugation to a CPP.
\end{abstract}

Keywords: model amphipathic peptide; cell-penetrating peptides; tacrine; blood-brain barrier; MCF-7 cells; anticancer activity; SH-SY5Y cells

\section{Introduction}

In 2018, cancer accounted for 9.6 million deaths worldwide and remains considered the second-leading cause of death [1]. For several years, the treatment of cancer has been based on tumor surgical removal (whenever possible), radiotherapy, and pharmacotherapy. However, successful treatment is still hard to achieve and conventional chemotherapy is associated with severe adverse effects on patients. Over the years, there has been an 
increased investment in the development of new compounds for cancer therapy. Still, only a few drugs have been successful to reach the clinics. As such, new strategies are required to efficiently develop more effective anti-cancer compounds.

Drug combination is a strategy increasingly used in oncology because it allows taking advantage of the maximum therapeutic effect of two or more drugs, by combining different mechanisms of action, while reducing required doses and, consequently, side effects. Drug repurposing is another strategy that allows overcoming the disadvantages of the traditional development of novel anticancer drugs, by searching for new therapeutic uses for drugs already approved for other indications. This allows the reduction of costs related to the development of new drugs while promoting a faster route towards the discovery of new therapies. Moreover, repurposed drugs have already been well characterized regarding their toxicity, dose efficacy, and plausible mechanism of action. Tacrine (Cognex $\left.{ }^{\circledR}\right)$, the first-generation acetylcholinesterase (AChE) inhibitor approved by the U. S. Food and Administration (FDA) for the treatment of Alzheimer's disease (AD) in 1993 [2,3], has already been tested on a variety of cancer cell lines, to assess its potential for repurposing to oncological pharmacotherapy [4-8]. Recently, our group also investigated the activity of Tacrine in breast tumor cells (MCF-7), both alone and in combination with 5-Fluorouracil (5-FU), in an attempt to improve the activity of this antineoplastic and reduce its therapeutic dose. The results demonstrated that Tacrine had antiproliferative activity at $50 \mu \mathrm{M}$, and its combination with 5-FU showed very promising results as it increased the cytotoxicity against those tumor cells (Figure 1) [8].

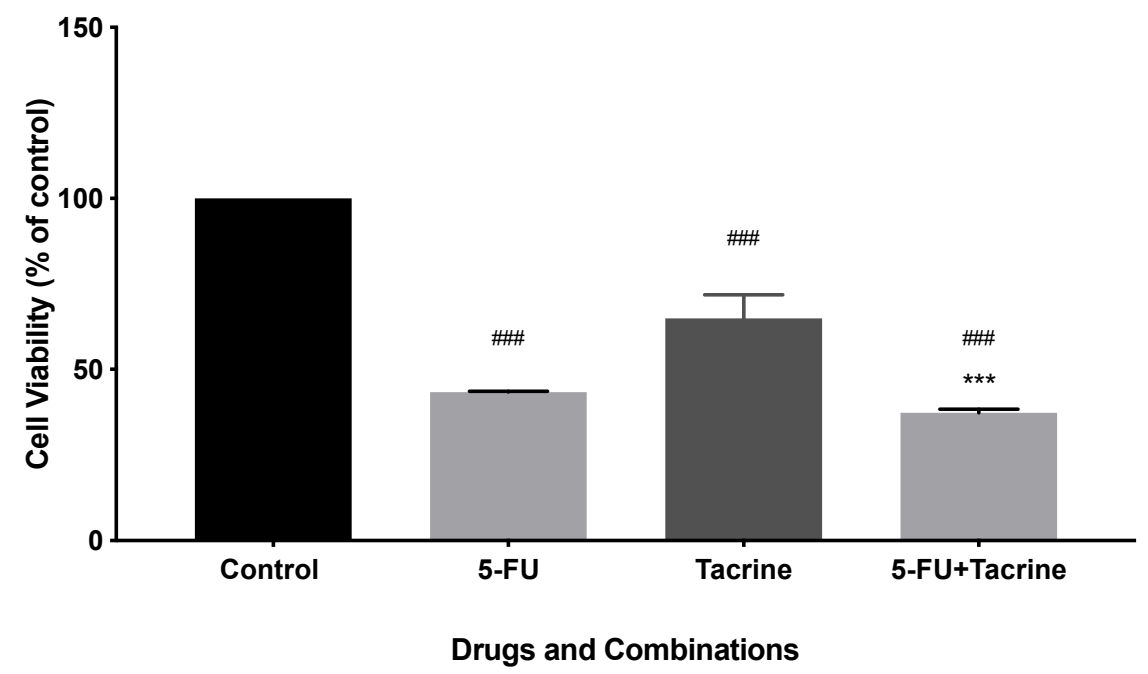

Figure 1. Effect of Tacrine and 5-Fluorouracil (5-FU) on the viability of MCF-7 cells. Results are presented as mean \pm standard error of the mean (SEM) and represent the viability of cells (\% of control) of three independent experiments $(n=3)$. \#\#\# $p<0.001$ vs. control; and ${ }^{* * *} p<0.001$ vs. single drug of the combination with more effect on cell viability reduction.

In view of the above, we decided to explore how the coupling of Tacrine with the cellpenetrating peptide (CPP) MAP might enhance its anti-cancer effect. CPPs are considered versatile carriers due to their unique ability to transport a wide range of molecules such as proteins, nucleic acids, contrast agents, drugs, and promote their intracellular delivery with limited toxicity [9]. Over recent years, a variety of new CPPs have been explored which displayed specific targeting properties towards cancer cell lines [10-12]. MAP (named after "model amphipathic peptide") is an artificial CPP that integrates both hydrophobic and hydrophilic residues in opposite sides of its $\alpha$-helical structure, resulting in a very well-defined amphipathic $\alpha$-helix [13]. This CPP, whose sequence is KLALKLALKALKAALKLA, has the ability to translocate a variety of compounds such as oligonucleotides [14], peptides [15], and small proteins (like cytochrome c) across cell membranes [16]. Moreover, in a study by Hällbrink et al., addressing the cellular uptake kinetics of several CPP, MAP 
was found to display the fastest cellular uptake, along with the ability to induce leakage by disturbing the membrane integrity at concentrations as low as $1 \mu \mathrm{M}$ [17].

The approach herein reported comprised the chemical synthesis of both the peptide MAP and its Tacrine conjugate, which was followed by a comparative assessment of (i) permeability on a well-known blood-brain barrier (BBB) model using hCMEC/D3 cells [18-20], and (ii) ability to inhibit AChE in vitro using the Ellman's method [21], of the conjugate and its parent compounds, that is, MAP and Tacrine individually. Next, the antiproliferative activity of these compounds was assessed in vitro, on breast (MCF-7) and human neuroblastoma (SH-SY5Y) cancer cell lines [21-23], using the standard 3-(4,5dimethyl-2-thiazolyl)-2,5-diphenyl-2H-tetrazolium bromide (MTT) reduction assay as well as evaluation of cellular morphological changes, to assess and compare the conjugate's toxicity and membrane disruption characteristics, in both cells lines.

\section{Results and Discussion}

\subsection{Chemical Synthesis of MAP and Its Tacrine Conjugate}

Peptide MAP (KLALKLALKALKAALKLA-NH ${ }_{2}$ ) was synthesized through Fmoc/tBu solid-phase peptide synthesis (SPPS) methodologies, see Supplementary Information (SI), Figure S1. After cleavage and purification of the crude product, as given in the SI, the isolated peptide was analyzed by high-performance liquid chromatography (HPLC, Figure 2A and Figure S2) and liquid chromatography-mass spectrometry (LC-MS, Figure S3). HPLC analysis showed a distinct peak [retention time $\left(\mathrm{r}_{\mathrm{t}}\right)=14.7 \mathrm{~min}$ ] corresponding to a purity degree of $100 \%$. The exact and observed (base peak) molecular mass of MAP obtained by LC-MS were 1876.50 and $1877.32 \mathrm{Da}$, respectively, which confirmed the successful synthesis of the target peptide as its quasi-molecular ion, $[\mathrm{M}+\mathrm{H}]^{+}$. It was also possible to observe minor peaks corresponding to different protonation states of the peptide.

Additionally, an alkyne-modified version of MAP was synthesized (Pra-MAP, 2 in Scheme 1) through the same methods described above (see also SI), in order to allow the conjugation of the CPP to the drug. The isolated peptide was analyzed by HPLC (Figure S4) and matrix-assisted laser desorption/ionization (MALDI-TOF, Figure S5).

The subsequent conjugation was achieved through one of the best known "click chemistry" reactions, the classical copper-catalyzed azide-alkyne coupling (CuAAC) or Huisgen's 1,3-dipolar cycloaddition (Scheme 1). CuAAC results in the chemoselective formation of a 1,2,3-triazole and can be carried out in either water or organic solvents under very mild conditions, while offering the possibility of being employed post-synthetically by use of purified units modified with alkynyl and azido functionalities, without need for additional protection of other functional groups. In this work, the CuAAC was promotedonresin, between an azide-modified derivative of Tacrine (1, Scheme 1) and the alkynemodified version of MAP (Pra-MAP, $\mathbf{2}$ in Scheme 1) in the presence of copper (I) bromide, diisopropylethylamine (DIEA), sodium ascorbate (NaAsc) and 2,6-lutidine, for $24 \mathrm{~h}$ at room temperature. Relevantly, the azide moiety could not be directly introduced in Tacrine through the reaction of its aniline group with azidoacetyl chloride, which was circumvented by first coupling chloroacetyl chloride onto tacrine, followed by conversion of the terminal chlorine into azide upon reaction with sodium azide (Scheme 1). After cleavage from the solid support and precipitation using tert-butylmethyl ether $\left(<0^{\circ} \mathrm{C}\right)$, the target MAPTacrine conjugate (3 in Scheme 1) was purified on a preparative scale, under a suitable gradient of acidified $\mathrm{H}_{2} \mathrm{O}(0.05 \%$ trifluoroacetic acid, TFA) and acetonitrile (ACN).

The structure of the Tacrine derivative 1 was confirmed by electrospray ionization mass spectrometry (ESI-MS), ${ }^{1} \mathrm{H}$ and ${ }^{13} \mathrm{C}$-NMR spectroscopy, whereas the peptide-drug conjugate 3 was characterized by HPLC and LC-MS, as given in detail in the SI (Figure 2B and Figures S11 and S12). 
A

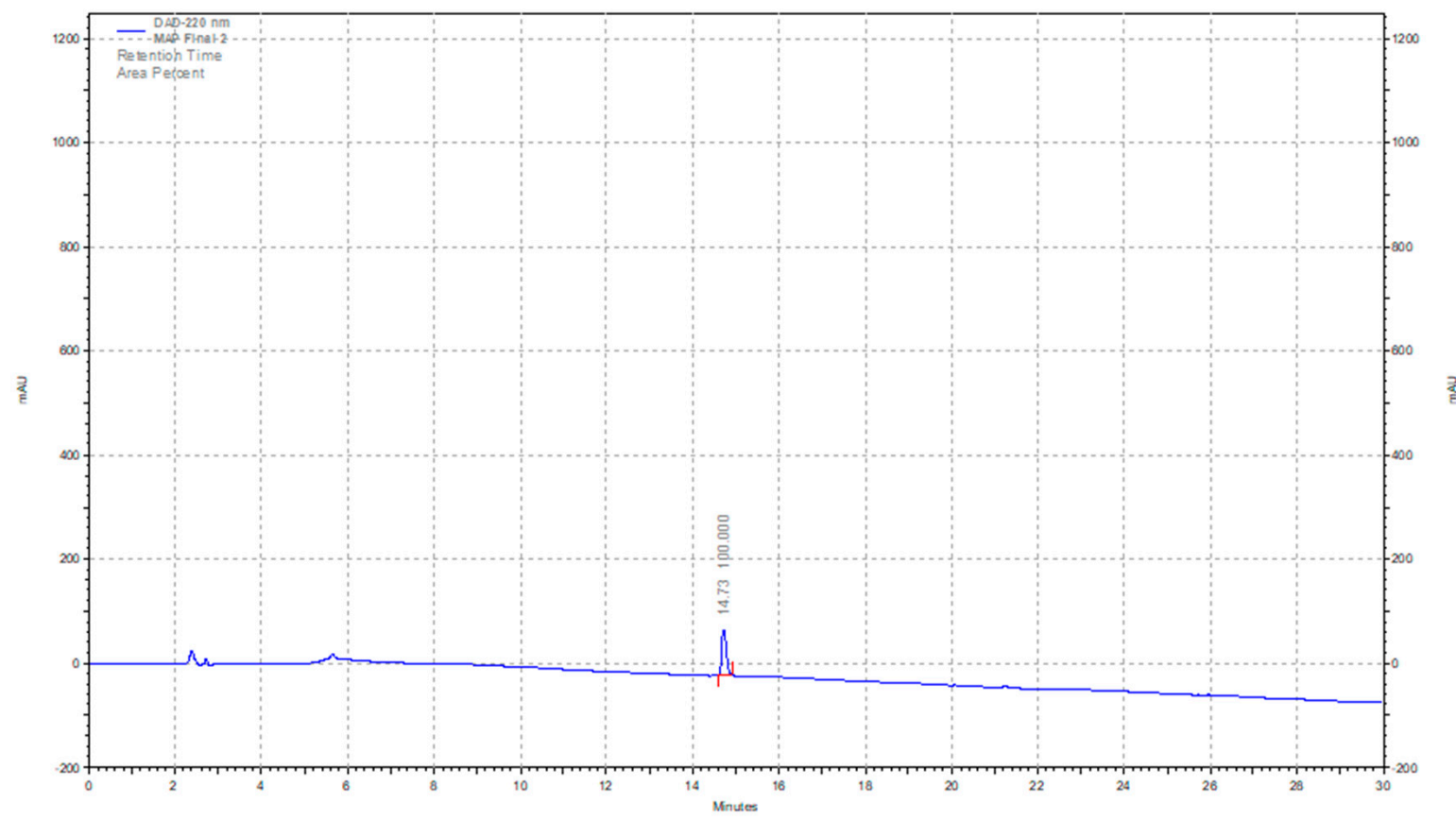

B

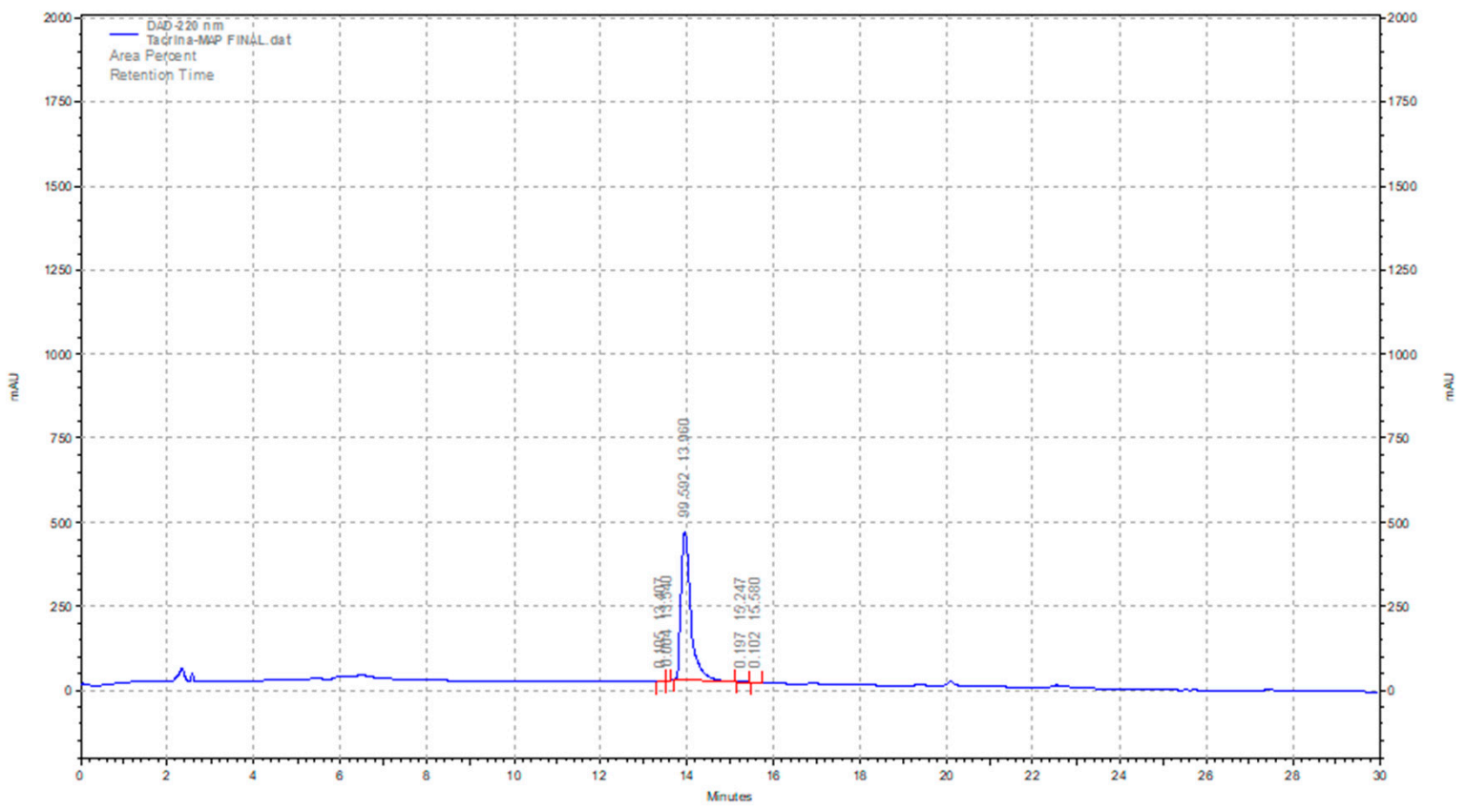

Figure 2. Chromatograms of synthetic MAP (A) and MAP-Tacrine conjugate (B), acquired with an HPLC system, with a C18 column, using ACN and acidified water ( $0.05 \%$ TFA) as eluent, in gradient mode (0-100\%), for 30 min, at a flow rate of $1 \mathrm{~mL} / \mathrm{min}$ and detection at $\lambda=220 \mathrm{~nm}$. 
<smiles>Nc1c2c(nc3ccccc13)CCCC2</smiles><smiles>O=C(Cl)CCl</smiles>

(tacrine) $\mathrm{t}=2 \mathrm{~h}$<smiles>O=C(CCl)Nc1c2c(nc3ccccc13)CCCC2</smiles>

$$
\mathrm{NaN}_{3}
$$

Acetone $/ \mathrm{H}_{2} \mathrm{O}$

$\mathrm{t}=24 \mathrm{~h}$

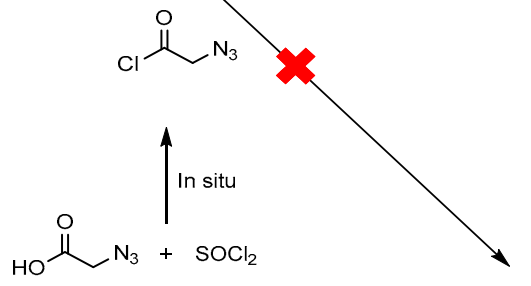<smiles></smiles>

(1)
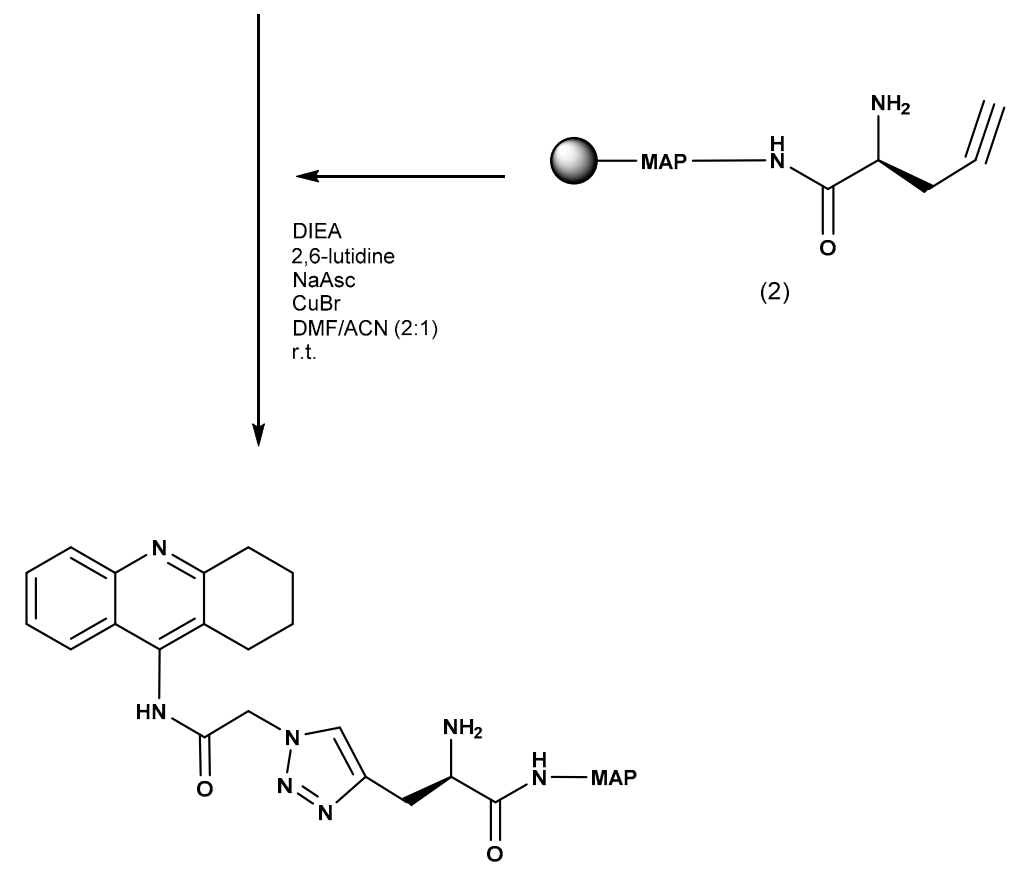

(3)

Scheme 1. Representation of the methodology applied for the synthesis of the Tacrine-MAP conjugate by SPPS. Tacrine-MAP (3) was obtained with a high level of purity (99.6\%). Red cross means that the reaction was executed but did not evaluated. Synthetic details, analytical and spectral data are supplied as Supplementary Information (SI, Figures S1-S15).

\subsection{Permeability Assays}

In order to evaluate the potential advantages of coupling MAP to Tacrine, as compared to Tacrine alone, we performed an in vitro BBB permeability study using hCMEC/D3 cells as a BBB model. This would not only allow determining whether peptide conjugation might cause loss of Tacrine's BBB permeability, as well as establish if the conjugate might cause barrier dysfunction. Trans-epithelial electrical resistance (TEER) measurements were conducted in order to assess barrier integrity throughout every measuring point 
of the experiment. These values are the variance of the electrical resistance across time (Figure S16). As TEER values demonstrated a lack of barrier integrity right from the start of the experiment (Table S1) with $0 \Omega / \mathrm{cm}^{2}$ and high standard deviation (SD) values, the results of this experiment were inconclusive (Figure S16).

\subsection{AChE In Vitro Inhibition Assay}

Considering that Tacrine is a well-known AChE inhibitor, it was necessary to know if its coupling to the $\mathrm{CPP}$ could alter its $\mathrm{AChE}$ inhibition properties. After performing the Ellman's method and calculating the $\mathrm{IC}_{50}$, we obtained a value of $5.508 \mathrm{nM}$ for Tacrine (Figure 3A) and $6068 \mathrm{nM}$ for the conjugate (Figure 3B), which clearly shows that the AChE inhibitory capacity of Tacrine is severely affected upon conjugation with MAP.

A

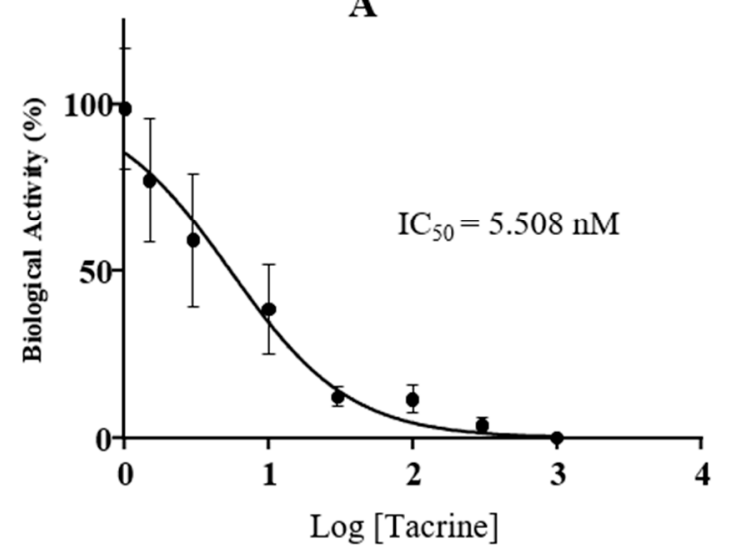

B

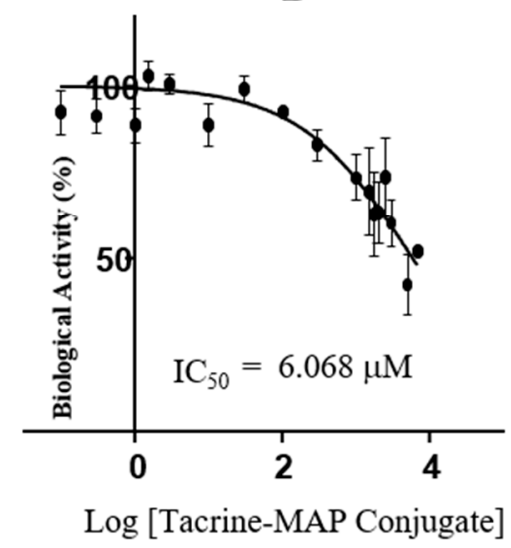

Figure 3. $\log$ [drug] vs. biological activity (\%) of Tacrine (A) and the conjugate (B). Results are presented in mean \pm standard error of mean (SEM). The $\mathrm{IC}_{50}$ of each compound is displayed next to the inhibition curves.

\subsection{Toxicity of Tacrine and Its MAP Conjugate to MCF-7 and SH-SY5Y Cells}

The toxicity of Tacrine and Tacrine-MAP towards MCF-7 (breast cancer) and SH-SY5Y (neuroblastoma) cells was tested at four different concentrations (1, 2.5, 5, and $10 \mu \mathrm{M})$, using the MTT reduction assay after a $24 \mathrm{~h}$-incubation period. Results show no significant differences in MTT reduction by Tacrine alone, when compared to control, for both cell lines (Figure 4). On the other hand, the MAP-Tacrine conjugate caused a significant mitochondrial dysfunction for the three higher concentrations, as reflected by the decrease in the ability to metabolize MTT both by MCF-7 $(2.5,5$ and $10 \mu \mathrm{M}-(73.1 \pm 4.4),(46.6 \pm 2.4)$ and (37.7 \pm 4.5$) \%$ of control cells, respectively) and, more pronouncedly, SH-SY5Y (2.5, 5 and $10 \mu \mathrm{M}-(42.4 \pm 5.2),(15.5 \pm 3.4)$ and $(8.7 \pm 4.4) \%$ of control cells, respectively) cells (Figure 4).

A cell count analysis was also conducted and corroborated data from MTT assays for both cell lines. Hence, it was confirmed that, while Tacrine did not affect the number of cells in culture up to $10 \mu \mathrm{M}$, the MAP-Tacrine conjugate significantly decreased cell count (Figure 5), thus displaying strong toxicity to both types of cancer cells. 


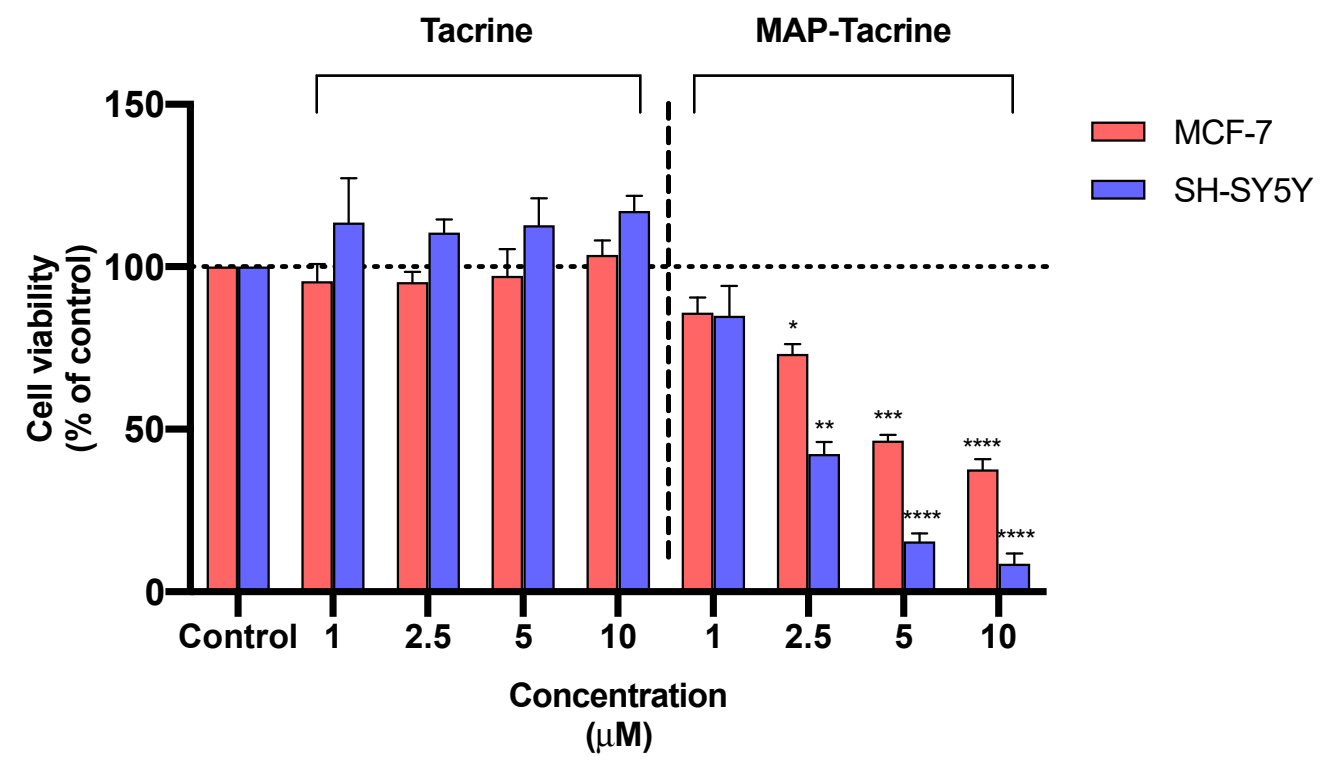

Figure 4. MCF-7 breast cancer and SH-SY5Y cell line cytotoxic effects of increasing concentrations of Tacrine, and Tacrine-MAP after a $24 \mathrm{~h}$ incubation. $\mathrm{H}_{2} \mathrm{O}$ was used in control. Significant differences (ANOVA test, followed by the with Dunnett's post hoc test): ${ }^{*} p<0.05,{ }^{* *} p<0.01,{ }^{* * *} p<0.001$ and $* * * * p 0.0001$ vs. Control. The values represent mean $\pm \operatorname{SEM}(n=3)$.

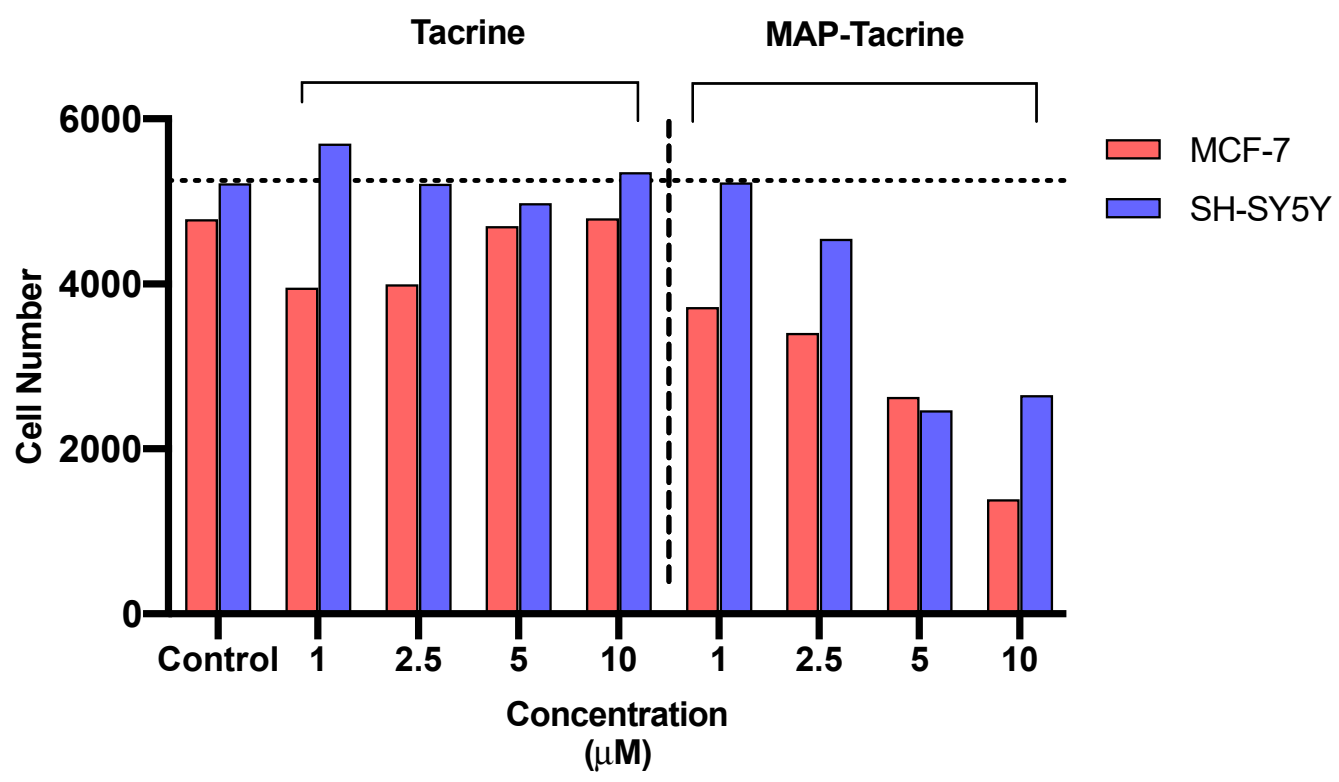

Figure 5. Cell count through Lionheart FX treatment of MCF-7 and SH-SY5Y cell lines with Tacrine and Tacrine-MAP $(1,2.5,5$, and $10 \mu \mathrm{M})$ after $24 \mathrm{~h}$ incubation $(n=1)$.

2.5. Determination of $I_{50}$ and Cell Count Analysis of Tacrine, MAP, and Tacrine-MAP against MCF-7

The effect of coupling MAP to Tacrine on the intrinsic cytotoxic activity of the parent peptide was also assessed on MCF-7 cells. Dose-response curves are depicted in Figure 6 and show similar $\mathrm{IC}_{50}$ values of $2.721 \mu \mathrm{M}$ and $2.732 \mu \mathrm{M}$ for both MAP and MAP-Tacrine, respectively. Moreover, cell count analysis after treatment with increasing concentrations of Tacrine, MAP, and MAP-Tacrine, show that while Tacrine has no significant effects, both $\mathrm{MAP}$ and its conjugate cause a severe drop in cell count at 20 and $25 \mu \mathrm{M}$ (Figure 7). 

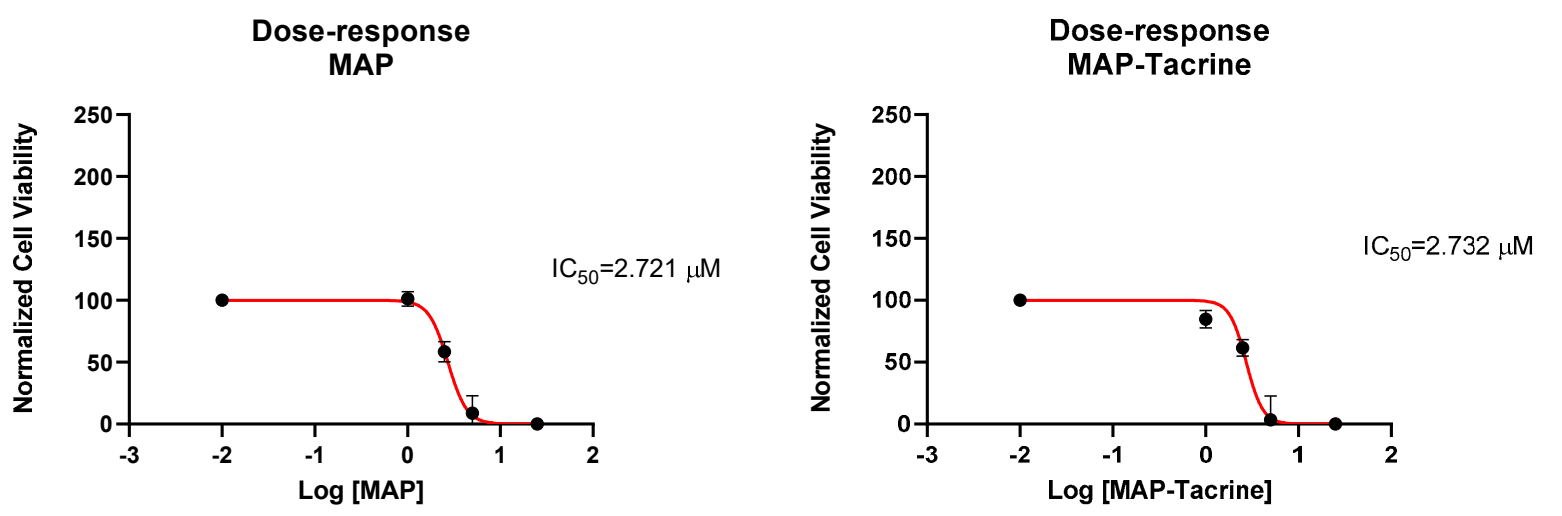

Figure 6. Dose-response curves (from triplicates) of MCF-7 cells viability with increasing concentrations (1, 2.5, 5, 10, 20, and $25 \mu \mathrm{M}$ ) of MAP (left plot) and MAP-Tacrine (right plot). IC50 values thus determined are shown next to the respective curves. The values represent mean $\pm \operatorname{SEM}(n=3)$.

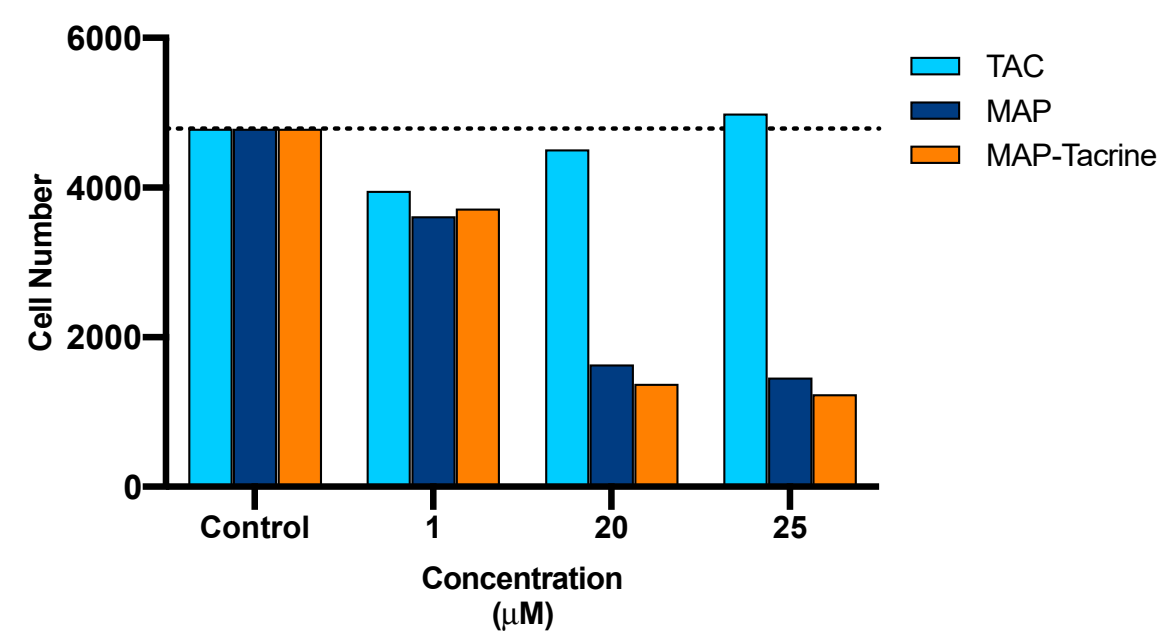

Figure 7. Cell count through Lionheart FX treatment of MCF-7 lines with Tacrine, MAP, and Tacrine$\operatorname{MAP}(1,20$, and $25 \mu \mathrm{M})$ after $24 \mathrm{~h}$ incubation $(n=1)$.

\subsection{Morphological Changes Caused by Tacrine, MAP, and Tacrine-MAP on MCF-7 Cells}

Morphological changes in MCF-7 cells after $24 \mathrm{~h}$ incubation with Tacrine, MAP, TacrineMAP at different concentrations were evaluated by Lionheart FX (Figure 8). No significant differences in cell morphology were observed between the control and Tacrine at all concentrations tested, as expected. In turn, MAP was confirmed to exert toxic effects on the cells, as significant differences are observed when comparing the effects of the peptide at 5,10 , 20 , and $25 \mu \mathrm{M}$ to control, including an increase of cells in suspension, loss of morphological features and cell death. Even at $2.5 \mu \mathrm{M}$, a slight increase of cells in suspension is already observed when compared to control. In the case of the MAP-Tacrine-conjugate, cell damage observed was similar to that caused by MAP alone, with substantial morphological changes and an increased level of cell death at higher concentrations (Figure 8). 

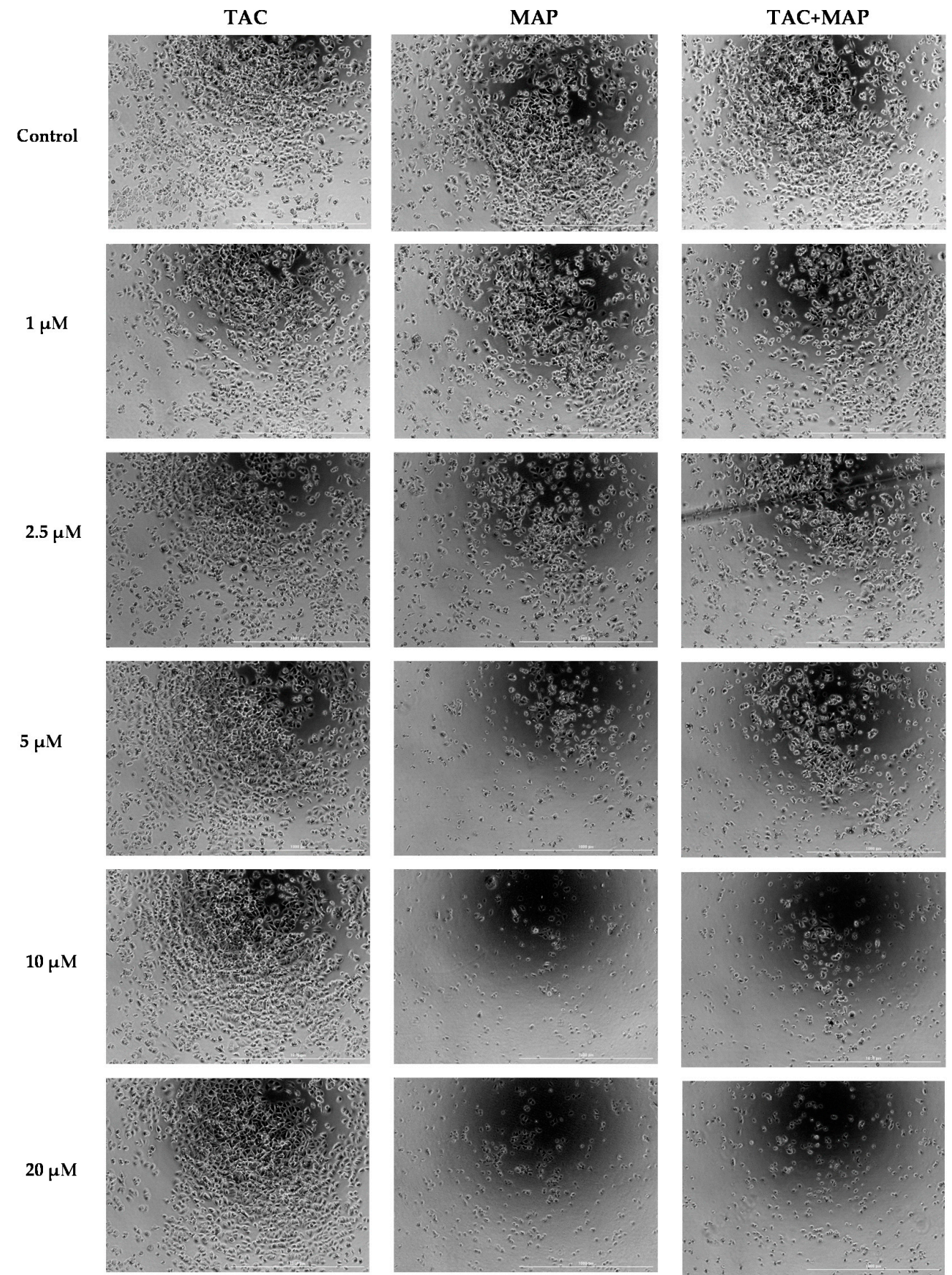

$25 \mu \mathrm{M}$
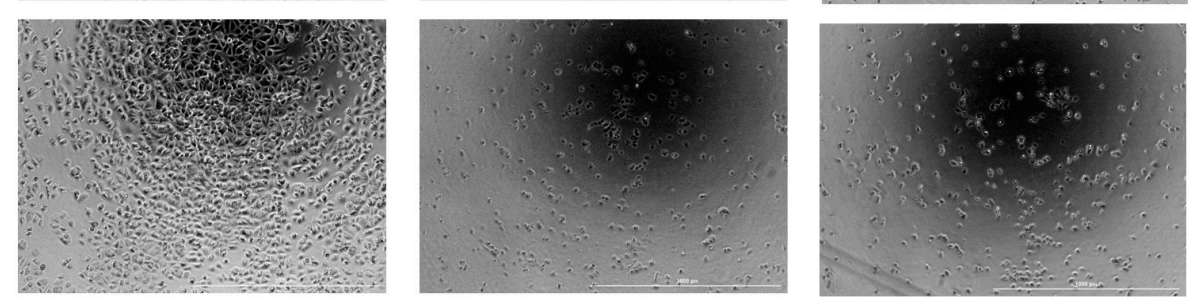

Figure 8. Micrographs (Lionheart FX of phase-contrast images) obtained for MCF-7 cells after a $24 \mathrm{~h}$ period of incubation with Tacrine, MAP, and MAP-Tacrine conjugate at different concentrations.

\subsection{Drug Interactions between Tacrine and MAP in the Conjugate}

In Figure 9, we can observe the impact of synergism and antagonism in the MAP combination with Tacrine. Using our data, it is possible to confirm that we have a synergistic 
effect in decreasing cell viability for lower doses of drug and peptide and, an additive effect for higher doses. The fact that we observe synergism only in smaller concentrations, allows us to think that any secondary effects associated with peptides can be minimized in conjugates such as the one we report. In addition, the effect of MAP and Tacrine can be considered super-additive and demonstrate action that is above what is expected from their individual potencies and efficacies at a lower concentration

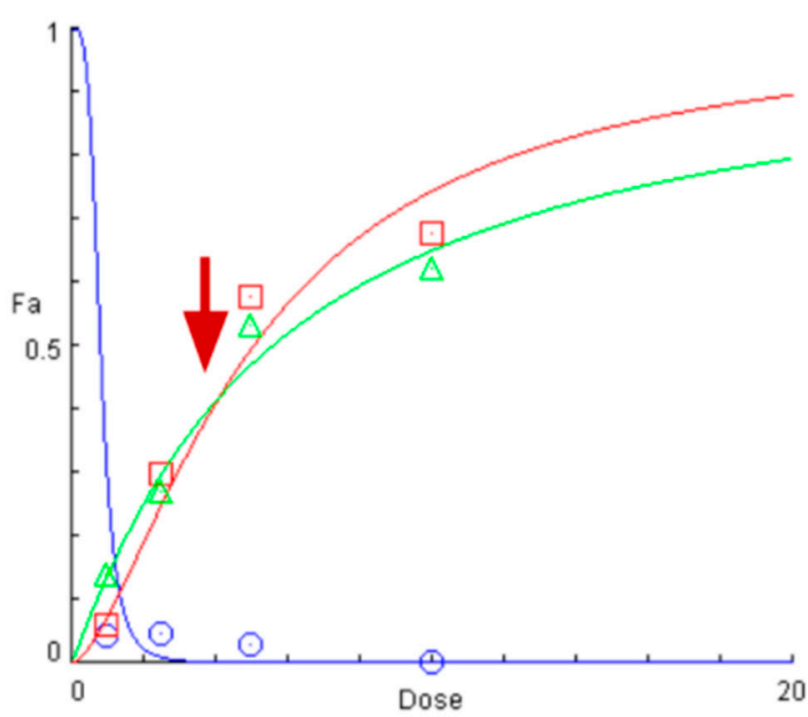

$$
\begin{array}{ll}
\bigcirc & \text { TAC } \\
\square & \text { MAP } \\
\triangle & \text { TACMAP }
\end{array}
$$

Figure 9. Dose-effect curves of Tacrine, MAP, and MAP-tacrine estimated by the unified theory using CompuSyn software. The dose was plotted on the $y$-axis as a function of effect level (Fa) on the $x$-axis to assess each drug behavior. Doses below the red arrow indicate better activity of Tacrine-MAP conjugate than MAP and tacrine alone.Experiments were conducted in triplicate $(n=3)$.

\section{Concluding Remarks}

The development of novel drugs for cancer therapy can be challenging, time-consuming, and expensive. As such, in order to overcome these hurdles, the combination and repurposing of drugs have been gaining prominence recently. Both strategies allow reducing overall costs and offer a fast-testing track for new therapeutic indications other than the original ones. In view of this and based on the previously reported anticancer potential of Tacrine, we explored how such potential might be enhanced by coupling this neuroactive drug to a CPP. To this end, we successfully synthesized both the selected CPP, MAP, and its Tacrine conjugate, formed via the well-known CuAAC click reaction. Both the conjugate and its parent building blocks were characterized by a toolbox of in vitro techniques, which allowed us to conclude that despite the conjugate no longer retaining the ability of the parent drug to cross the BBB or inhibit $\mathrm{AChE}$, it displays significant cytotoxic action against two cancer cell lines, namely breast (MCF-7) and neuroblastoma (SH-SY5Y) cells. This cytotoxic action was coherently observed in different types of assays, including the assessment of cell counts and morphological changes. Relevantly, this same cytotoxic effect was observed for the MAP peptide alone, which, on the one hand, puts into question if Tacrine is really important for the effects observed, and on the other, highlights a cell destructive rather than a cell-penetrating role for the peptide. This highlights the potential use of MAP not as a classic CPP, but more as an antimicrobial peptide (AMP), able to destroy cell membranes even at low concentration levels, leading to fast cell death. Indeed, the behavior observed for both MAP and its Tacrine conjugate in this work closely resemble those reported in previous works focused on AMP, including examples where these AMP were found to exert selective membrane toxicity against malignant cells [17,24-27]. The observation of alterations on membrane integrity caused by MAP or its Tacrine conjugate has no precedent in the literature but, interestingly, comes into agreement with very recent 
reports highlighting the lytic character of CPP-drug conjugates comprising heterocyclic drug moieties [27,28].

\section{Materials and Methods}

\subsection{MAP and Conjugate Synthesis}

\subsubsection{General Peptide Synthesis Procedure}

The peptide (C-terminal amide) was assembled by Fmoc/tBu SPPS methodologies. The resin was preconditioned for $15 \mathrm{~min}$ in $N, N$-dimethylformamide (DMF). The initial Fmoc deprotection step was carried out for 20 min using 20\% piperidine in DMF. The C-terminal amino acid was then coupled to the deprotected Rink amide resin, using five molar equivalents (eq) of the Fmoc-protected amino acid in DMF, 5 eq of hexafluorophosphate benzotriazole tetramethyl uronium (HBTU) in DMF, and 10 eq of $N$-ethyl- $N, N-$ diisopropylamine; this coupling step was carried out for $1 \mathrm{~h}$. The remaining amino acids were sequentially coupled in the $\mathrm{C} \rightarrow \mathrm{N}$ direction by means of similar deprotection and coupling cycles. Following the completion of the sequence assembly, the peptide was released from the resin with concomitant removal of side-chain protecting groups, by a $2 \mathrm{~h}$ acidolysis at room temperature using a TFA-based cocktail containing triisopropysilane and water $(95: 2.5: 2.5 \mathrm{v} / \mathrm{v} / \mathrm{v})$ as scavengers. The synthesis crude was obtained by precipitation using tert-butylmethyl ether $\left(<0{ }^{\circ} \mathrm{C}\right)$.

\subsubsection{General Analysis Procedure}

Peptide or conjugate analysis and purity degree were determined by HPLC, using a Hitachi-Merck Elite LaChrom system from Hitachi High-Technologies America (Schaumburg, IL, USA) equipped with a quaternary pump, a thermostatted automated sampler, a diode-array detector (DAD), and a reverse phase C18 Nucleodur gravity column (Macherey-Nagel Inc., Bethlehem, PA, USA) with $5 \mu \mathrm{m}$ particle size and the dimensions $4 \mathrm{~mm}$ ID $\times 125 \mathrm{~mm}$. The samples were solubilized in aqueous acetic acid $(10 \% \mathrm{v} / \mathrm{v})$ and eluted over a gradient of $100 \%$ solvent $\mathrm{A}\left(100 \% \mathrm{H}_{2} \mathrm{O}\right.$ with $0.05 \%(v / v)$ TFA) to reach $100 \%$ Solvent B (ACN with $0.05 \%(v / v)$ TFA) for $30 \mathrm{~min}$, at a flow rate of $1 \mathrm{~mL} / \mathrm{min}$ and detection at $\lambda=220 \mathrm{~nm}$.

Synthetic crudes were purified by a preparative HPLC system (LaPrep Sigma VWR, Pennsylvania, USA), equipped with a UV detector, a quaternary LPG pump injection with a fractionation valve pump, and a reverse-phase C18 column $(250 \times 25 \mathrm{~mm}$ ID with $5 \mu \mathrm{M}$ pore size, Merck, Darmstadt, Germany). The mobile phase was a gradient elution of acidified $\mathrm{H}_{2} \mathrm{O}(0.05 \%$ TFA) / ACN mixtures that are reported in the SI. Fractions containing the pure product (determined by HPLC) were pooled and freeze-dried.

MS analysis was performed on an LTQ Orbitrap ${ }^{\mathrm{TM}} \mathrm{XL}$ hybrid mass spectrometer (Thermo Fischer Scientific, Bremen, Germany) controlled by LTQ Tune Plus 2.5.5 (Thermo Fischer Scientific, Bremen, Germany) and Xcalibur 2.1.0 (Thermo Fischer Scientific, Bremen, Germany). The electrospray ionization source settings were as follows: source voltage, $3.1 \mathrm{kV}$; the capillary temperature was $275^{\circ} \mathrm{C}$ with a sheath gas flow rate at 40 and auxiliary gas flow rate at 10 (arbitrary unit as provided by the software settings). The capillary voltage was $36 \mathrm{~V}$ and the tube lens voltage $110 \mathrm{~V}$.

The direct electrospray ionization-ion trap mass spectrometry (ESI-IT MS) analysis was performed on a Finnigan Surveyor LCQ DECA XP MAX mass spectrometer from ThermoElectron Corporation (Waltham, MA, USA), and the LC-MS analysis was performed on the same equipment, coupled to a Finnigan Surveyor HPLC, equipped with a DAD Plus Detector, an Autosampler Plus, and an LC Pump Plus. MALDI-TOF/TOF matrixassisted desorption/ionization mass spectrometry was performed using a Bruker Daltonics UltrafleXtreme (Bruker, MA, USA).

MS data handling software (Xcalibur QualBrowser software, Thermo Fischer Scientific, Bremen, Germany) was used to obtain the confirmation of the synthetic peptides by their exact $\mathrm{m} / \mathrm{z}$ value. All target products were obtained with correct mass spectral data and high chromatographic purity. 


\subsection{Cell Culture}

\subsubsection{Materials}

All plastic sterile material was obtained from Starstedt (Nümbrecht, Germany), except 48-well plates, 12-well plates, and tissue cultures flasks used in the permeability assays that were purchased from Corning Inc (Corning, New York, NY, USA), VWR (Radnor, PA, USA) and Orange Scientific (Braine-l'Alleud, Belgium), respectively. Trypsin-EDTA used for the cytotoxicity studies was acquired from Alfagene (Carcavelos, Portugal). Dulbecco's Modified Eagle medium (DMEM), Dimethyl-sulfoxide (DMSO), and Fetal Bovine Serum (FBS) used in SH-SY5Y cells and MCF-7 cells were purchased from Merck (Kenilworth, NJ, USA). Endothelial Cell Growth Medium-2 (EBM-2) was acquired from Lonza (Basel, Switzerland). Regarding the cytotoxicity assays, Dulbecco's Phosphate Buffered Saline (PBS) without calcium and magnesium, the solution of penicillin $(10,000 \mathrm{U} / \mathrm{mL})$ and streptomycin $(10 \mathrm{mg} / \mathrm{mL})$, the Hank's Balanced Salt Solution (HBSS), and the 3-(4,5-dimethyl2-thiazolyl)-2,5-diphenyl-2H-tetrazolium bromide (MTT) powder were purchased from Sigma-Aldrich, while other reagents from other assays were also acquired from there, including hydrocortisone, HEPES, ascorbic acid, basic fibroblast growth factor, the enzyme acetylcholinesterase (AChE from the electric eel), 5,5'-dithiobis-(2-nitrobenzoic acid), acetylcholine iodide, and Tacrine. For the permeability assays, FBS, penicillin, streptomycin, trypsin-EDTA, collagen I rat protein, HBSS, PBS, and chemically defined lipid concentrate were purchased from Gibco (Waltham, MA, USA). Triton X-100 was acquired from SpiChem (Gessate, Italy). The human immortalized endothelial cell line (hCMEC/D3) was purchased from Cedarlane (Hornby, ON, Canada). The BD Falcon ${ }^{\circledR}$ cell culture inserts (transparent polyethylene terephthalate membrane) with a $0.4 \mu \mathrm{m}$ pore size were from BD Biosciences (Franklin Lakes, NJ, USA).

\subsubsection{Cell Culture Conditions}

The hCMEC/D3 cells were initially maintained in $25 \mathrm{~cm}^{2}$ culture flasks after thawing with complete growth medium [EBM-2 medium was supplemented with 5\% FBS, bFGF (1 ng/mL), penicillin-streptomycin (final concentration of $100 \mathrm{U} / \mathrm{mL}$ and $0.1 \mathrm{mg} / \mathrm{mL}$, respectively), chemically defined lipid concentration $(1 / 100, v / v)$, ascorbic acid $(5 \mu \mathrm{g} / \mathrm{mL})$, hydrocortisone $(1.4 \mu \mathrm{M})$, and HEPES $(10 \mathrm{mM})]$ in an incubator at $37^{\circ} \mathrm{C}$ and $5 \% \mathrm{CO}_{2}$. After the first passage, the cells were maintained in $75 \mathrm{~cm}^{2}$ culture flasks. The number of cell passages used ranged from 35 to 41 . Cell passaging by trypsinization was done every 3-4 days and the culture medium was replaced every two days.

MCF-7 cells and SH-SY5Y cells were maintained in a culture flask $\left(25 \mathrm{~cm}^{2}\right)$ with full growth medium DMEM supplemented with $10 \%$ FBS and penicillin and streptomycin (final concentration of $100 \mathrm{U} / \mathrm{mL}$ and $0.1 \mathrm{mg} / \mathrm{mL}$, respectively) were kept in an incubator at $37^{\circ} \mathrm{C}$ and $5 \% \mathrm{CO}_{2}$. In the culture flask, the medium was changed at least twice a week, while trypsinization was done at least once a week. Trypsinization was made when there was more than $80 \%$ confluence of the monolayer and cell passages used were lower than 35 .

\subsection{Permeability Studies}

For the permeability studies, the model was set with the insert $(0.4 \mu \mathrm{m}$ pore) being coated with rat tail collagen type I $(50 \mu \mathrm{g} / \mathrm{mL})$ for $1 \mathrm{~h}$, to promote cell adherence and washed two times with PBS. The cells were seeded at a density of $2.5 \times 10^{4}$ cells $/ \mathrm{cm}^{2}$ on the AP side of the filter. The endothelial hCMEC/D3 cells were cultured in the insert for eight days at the conditions referred to $\left(37^{\circ} \mathrm{C}\right.$ and $\left.5 \% \mathrm{CO}_{2}\right)$. The culture medium was replaced every two days. The TEER was used to analyze the monolayer integrity and it was periodically determined using an endothelial voltammeter (World Precision Instruments, Sarasota, FL, USA). The resistance, expressed in $\Omega / \mathrm{cm}^{2}$, was achieved by subtracting the value of an empty filter from the value of each measurement. The TEER values obtained throughout the maintenance of the cells were constant. On the day of the assays, $500 \mu \mathrm{L}$ of Tacrine, MAP, and Tacrine-MAP diluted in HBSS (concentration of $40 \mu \mathrm{M}$ for all compounds) was added to the upper compartment. All conditions were done in 
triplicate. Before and after adding the compound to the AP side, $750 \mu \mathrm{L}$ of preheated HBSS were inserted in the lower compartment, to prevent tearing the membrane.

During the assay, the cells were kept at $37^{\circ} \mathrm{C}$ in an orbital shaker incubator (100 rpm). $200 \mu \mathrm{L}$ of samples were taken from the BL side at predetermined time points $(15,30,45$, $60,90,120,180$, and $240 \mathrm{~min}$ ). To replace the taken volume, $200 \mu \mathrm{L}$ of preheated HBSS was added. At every time interval before adding the samples, the TEER was measured in all conditions to detect changes in the monolayer confluence. The values of this electrical resistance are expressed as the variance in relation to the TEER value of the beginning of the assay and they are represented as mean $\pm \mathrm{SD}$. At the end of the experiment, samples of the AP side were also taken.

\subsection{Cytotoxicity Assays}

For cytotoxicity evaluation, MCF-7 cells were seeded in 48-well plates at a density of $25 \times 10^{4}$ cells per well in a final volume of $250 \mu \mathrm{L}$ of culture medium. Cells were given $24 \mathrm{~h}$ to attach before they were incubated with the compounds in the study. The cells were treated with different concentrations $(1,2.5,5,10,20$, and $25 \mu \mathrm{M})$ of Tacrine, MAP, and Tacrine-MAP for $24 \mathrm{~h}$ with a final volume per well of $250 \mu \mathrm{L}$ of complete medium. $\mathrm{H}_{2} \mathrm{O}$ and DMSO were used in control, with the volume added being the one used for each concentration.

SH-SY5Y cells were seeded in 96 well-plate at a density of 18,000 cells per well at the final volume of $200 \mu \mathrm{L}$. Cells were given $24 \mathrm{~h}$ to attach before they were incubated with the compounds in the study. The cells were treated with different concentrations $(1,2.5,5$, and $10 \mu \mathrm{M}$ ) of Tacrine, MAP, and Tacrine-MAP for $24 \mathrm{~h}$ with a final volume per well of $200 \mu \mathrm{L}$ of complete medium. $\mathrm{H}_{2} \mathrm{O}$ and DMSO were used in control, with the volume added being the one used for each concentration. After the period of incubation, the MTT reduction was performed in both cell lines.

\section{MTT Reduction Assay}

The MTT assay can be used to assess the cell's metabolic activity [26]. MTT, a watersoluble compound, is reduced by the complex II of the mitochondrial respiratory chain to a water-insoluble blue formazan product. Only viable cells can metabolize MTT, so the metabolic activity is proportional to the quantity of formazans produced). After a $24 \mathrm{~h}$ incubation with the compounds in the study at $37^{\circ} \mathrm{C}$ with $5 \% \mathrm{CO}_{2}$, the cells were retrieved from the incubator and the medium was discarded. A previously warmed medium with MTT $(0.5 \mathrm{mg} / \mathrm{mL})$ was added $\left(200 \mu \mathrm{L}\right.$ per well) and cells were maintained for $3 \mathrm{~h}$ at $37^{\circ} \mathrm{C}$ and $5 \% \mathrm{CO}_{2}$. Then the medium was aspirated again and DMSO $(200 \mu \mathrm{L})$ was added to cause cellular lysis and solubilize the formazan crystals. The complete dissolution of the crystals was obtained by putting the plates on a shaking platform for $15 \mathrm{~min}$, protected from light. The absorbance was read at $570 \mathrm{~nm}$ in a microplate reader (BioTeK Model Synergy HT, Winooski, VT, USA). Results were expressed as percentage of control cells.

\subsection{Ellman's Method}

To assess if the chemical linkage of MAP to Tacrine interferes with the latter's ability to inhibit the AChE, we chose Ellman's method [29] introduced in 1961. This method is still widely used with some modifications [30]. Apart from its main function, this enzyme can efficiently hydrolyze a sulfur analogue of acetylcholine-acetylthiocholine. The products of this reaction are acetate and thiocholine, with the latter reacting with the highly reactive DNTB ion, generating a 5-thio-2-nitrobenzoate anion that has a yellow color and it can be detected by measuring the increase of absorbance at $412 \mathrm{~nm} .3 \mathrm{~mL}$ of assay medium (phosphate buffer pH $7.4+150 \mu \mathrm{L}$ DNTB $0.01 \mathrm{M}+30 \mu \mathrm{L}$ AChE 2.0 units $/ \mathrm{mL}$ ) was put into cuvettes. The positive control was incubated at $37^{\circ} \mathrm{C}$ for $15 \mathrm{~min}$ and then was added $150 \mu \mathrm{L}$ of substrate (acetylthiocholine $0.01 \mathrm{M}$ ). For the experiments with Tacrine and the conjugate, the test compounds were added to the assay solution and incubated at the same temperature for the same period, adding $150 \mu \mathrm{L}$ of substrate after the incubation. After the 
addition of substrate to the assay medium, it was measured the increase in absorbance at $412 \mathrm{~nm}$ for $30 \mathrm{~s}$ intervals for $5 \mathrm{~min}(300 \mathrm{~s})$ at $37^{\circ} \mathrm{C}$.

The absorbance was measured in the JENWAY 6300 Spectrophotometer. All conditions were made in triplicates. The value of the initial absorbance was subtracted to the value of the absorbance at $300 \mathrm{~s}$ and that was considered as the biological activity.

\subsection{Cell Morphology Visualization and Cell Count Analysis}

After the treatments, cell morphology and growth were assessed by the contrast phase microscope Lionheart FX (Biotech, VT, USA) with the use of Gen5 software (Biotech, USA). The cell count of MCF-7 cells was assessed by Lionheart FX (Biotech, USA) using Gen5 software (Biotech, USA).

\subsection{Analysis of Drug Interactions}

To quantify the interaction of Tacrine and MAP in the conjugate, the dose-effect curves were estimated by the unified theory, introduced by Chou and Talalay [31] using CompuSyn software (ComboSyn, Inc., New York, NY, USA). The dose was plotted on the $y$-axis as a function of effect level (Fa) on the $x$-axis to assess the drugs' behavior. Experiments were conducted in triplicate $(n=3)$ with three replications.

\subsection{Statistical Analysis}

Results are expressed in mean \pm standard error of the mean (SEM). To assess whether the data was normal or not, the Student's $t$-test was performed. If data distribution was normal an ordinary one-way ANOVA statistical analysis was executed, by the Student's t-test. Statistical significance was accepted when $p<0.05$. The GraphPad Prism 8 software (San Diego, CA, USA) was used to perform all statistical analysis.

Supplementary Materials: Supplementary Materials can be found at https:/ /www.mdpi.com/14 22-0067/22/1/242/s1. Figure S1: Structure of MAP; Figure S2: Chromatogram of synthetic MAP, acquired with an HPLC system, with a C18 column, using ACN and acidified water ( $0.05 \%$ TFA) as eluent, in gradient mode $(0-100 \%)$, for $30 \mathrm{~min}$, at a flow rate of $1 \mathrm{~mL} / \mathrm{min}$ and detection at $\lambda$ $=220 \mathrm{~nm}$; Figure S3: Mass spectrum (LC-ESI/Orbitrap MS, positive mode) of MAP; Figure S4: Chromatogram of synthetic crude of Pra-MAP (2), acquired with an HPLC system, with a C18 column, using ACN and acidified water $(0.05 \%$ TFA) as eluent, in gradient mode $(0-100 \%)$, for $30 \mathrm{~min}$, at a flow rate of $1 \mathrm{~mL} / \mathrm{min}$ and detection at $\lambda=220 \mathrm{~nm}$; Figure S5: MALDI-TOF mass spectrometry of synthetic crude of Pra-MAP; Figure S6: Chemical equation translating the synthesis of N-chloroacetyl-tacrine; Figure S7: Mass spectrum (LC-ESI/Orbitrap MS, positive mode) of Nchloroacetyl-tacrine; Figure S8: ${ }^{1} \mathrm{H}$ NMR spectrum of N-chloroacetyl-tacrine $\left(400 \mathrm{MHz}, \mathrm{CDCl}_{3}\right)$. $\delta(\mathrm{ppm}), 8.52(\mathrm{~s}, 1 \mathrm{H}), 8.00(\mathrm{~d}, \mathrm{~J}=8.4 \mathrm{~Hz}, 1 \mathrm{H}), 7.75(\mathrm{~d}, \mathrm{~J}=8.4 \mathrm{~Hz}, 1 \mathrm{H}), 7.67-7.57(\mathrm{~m}, 1 \mathrm{H}), 7.51-7.41$ $(\mathrm{m}, 1 \mathrm{H}), 4.34(\mathrm{~s}, 2 \mathrm{H}), 3.13(\mathrm{t}, \mathrm{J}=6.5 \mathrm{~Hz}, 2 \mathrm{H}), 2.80(\mathrm{t}, \mathrm{J}=6.4 \mathrm{~Hz}, 2 \mathrm{H}), 2.01-1.90(\mathrm{~m}, 2 \mathrm{H}), 1.89-1.81(\mathrm{~m}$, $2 \mathrm{H})$.; Figure S9: Chemical equation translating the synthesis of N-azidoacetyl-tacrine (1); Figure S10: Mass spectrum (LC-ESI/Orbitrap MS, positive mode) of N-azidoacetyl-tacrine (1); Figure S11: ${ }^{1} \mathrm{H}$ NMR of N-azidoacetyl-Tacrine (400 MHz, CD3OD). $\delta(\mathrm{ppm}), 7.92(\mathrm{dd}, \mathrm{J}=14.4,8.4 \mathrm{~Hz}, 2 \mathrm{H}), 7.72-7.66$ $(\mathrm{m}, 1 \mathrm{H}), 7.57-7.51(\mathrm{~m}, 1 \mathrm{H}), 4.25(\mathrm{~s}, 2 \mathrm{H}), 3.12(\mathrm{t}, \mathrm{J}=6.5 \mathrm{~Hz}, 2 \mathrm{H}), 2.84(\mathrm{t}, \mathrm{J}=6.5 \mathrm{~Hz}, 2 \mathrm{H}), 2.01-1.94(\mathrm{~m}$, $2 \mathrm{H}), 1.92-1.84(\mathrm{~m}, 2 \mathrm{H})$; Figure S12: ${ }^{13} \mathrm{CNMR}$ of $\mathrm{N}$-azidoacetyl-Tacrine $\left(101 \mathrm{MHz}, \mathrm{CD}_{3} \mathrm{OD}\right) .8(\mathrm{ppm})$, $169.11(\mathrm{C}=\mathrm{O}), 161.01(\mathrm{C}), 146.98(\mathrm{C}), 140.99(\mathrm{C}), 130.63(\mathrm{CH}), 129.61(\mathrm{CH}), 127.91(\mathrm{CH}), 127.54(\mathrm{CH})$, $125.47(\mathrm{CH}), 123.85(\mathrm{CH}), 52.99\left(\mathrm{CH}_{2}\right), 34.08\left(\mathrm{CH}_{2}\right), 26.18\left(\mathrm{CH}_{2}\right), 23.43\left(\mathrm{CH}_{2}\right), 23.22\left(\mathrm{CH}_{2}\right)$. Figure S13: Chemical equation of the synthesis (top) and structure (bottom) of the MAP-Tacrine conjugate 3. Figure S14: Chromatogram of synthetic MAP-Tacrine conjugate 3, acquired with an HPLC system, with a $\mathrm{C} 18$ column, using ACN and acidified water ( $0.05 \%$ TFA) as eluent, in gradient mode (0-100\%), for $30 \mathrm{~min}$, at a flow rate of $1 \mathrm{~mL} / \mathrm{min}$ and detection at $\lambda=220 \mathrm{~nm}$. Figure S15: Mass spectrum (LCESI/Orbitrap MS, positive mode) of the Tacrine-MAP conjugate. Figure S16: Results are expressed in mean $\pm \mathrm{SD}, n=3$ independent experiments. TEER measurements for all compounds' overall time-points. Two-way ANOVA test followed by Tukey's post hoc test. No significant differences were observed; Table S1: Initial and final values of $\triangle \mathrm{TEER}$. Results represented as mean $\pm \mathrm{SD}, n=3$ independent experiments. 
Author Contributions: N.V. conceived of and designed the project. C.A., S.S., and A.C. performed the experiments. S.S. and N.V. analyzed the data and wrote the paper. All authors contributed to the interpretation of the results. All authors provided critical feedback and helped shape the research, analysis, and manuscript. All authors have read and agreed to the published version of the manuscript.

Funding: This work was financed by FEDER-Fundo Europeu de Desenvolvimento Regional through the COMPETE 2020-Operational Programme for Competitiveness and Internationalization (POCI), Portugal 2020, and by Portuguese funds through FCT-Fundação para a Ciência e a Tecnologia, in a framework of CINTESIS, R\&D Unit (reference UIDB/4255/2020), iMed.ULisboa (UID/DTP/04138/ 2013), LAQV-REQUIMTE (UIDB/50006/2020), and the "Institute for Research and Innovation in Health Sciences" (UID/BIM/04293/2019).

Institutional Review Board Statement: Not applicable.

Informed Consent Statement: Not applicable.

Acknowledgments: N.V. also thanks for support FCT and FEDER (European Union), award number IF/00092/2014/CP1255/CT0004. S.S. thanks FCT for supporting this article with her Ph.D. Grant (PD/BD/135456/2017) and Ph.D. Programme in Medicines and Pharmaceutical Innovation (i3DU) from the University of Lisbon (Portugal) and the University of Porto (Portugal) for all support. D.D. acknowledges FCT for funding her Ph.D. grant (SFRH/BD/140734/2018).

Conflicts of Interest: The authors declare no conflict of interest.

$\begin{array}{ll}\text { Abbreviations } & \\ \text { 5-FU } & \text { 5-Fluorouracil } \\ \text { AChE } & \text { Acetylcholinesterase } \\ \text { ACN } & \text { Acetonitrile } \\ \text { AD } & \text { Alzheimer Disease } \\ \text { AMP } & \text { Antimicrobial peptide } \\ \text { BBB } & \text { Blood brain barrier } \\ \text { CPP } & \text { cell penetrating peptide } \\ \text { CuAAC } & \text { Copper-catalyzed azide-alkyne coupling } \\ \text { DAD } & \text { Diode-array detector } \\ \text { DIEA } & \text { Diisopropylethylamine } \\ \text { DMF } & \text { N,N-dimethylformamide } \\ \text { ESI-IT MS } & \text { Electrospray ionization-ion trap mass spectrometry } \\ \text { FDA } & \text { Food and Drug Administration } \\ \text { HOBt } & \text { 1-hydroxybenzotriazole } \\ \text { HPLC } & \text { High performance liquid chromatography } \\ \text { LC-MS } & \text { Liquid chromatography-mass spectrometry } \\ \text { MALDI-TOF/TOF } & \text { Matrix assisted desorption/ionization mass spectrometry } \\ \text { MAP } & \text { model amphipathic peptide } \\ \text { MTT } & \text { 3-(4,5-dimethyl-2-thiazolyl)-2,5-diphenyl-2H-tetrazolium bromide } \\ \text { MW } & \text { Microwave } \\ \text { NaAsc } & \text { Sodium ascorbate } \\ \text { SD } & \text { Standard deviation } \\ \text { SEM } & \text { Standard error of the mean } \\ \text { SPPS } & \text { solid-phase peptide synthesis } \\ \text { TEER } & \text { Trans-epithelial electrical resistance } \\ \text { TFA } & \text { Trifluoroacetic acid }\end{array}$

\section{References}

1. Siegel, R.L.; Miller, K.D.; Jemal, A. Cancer statistics, 2018. CA. Cancer J. Clin. 2018, 68, 7-30. [CrossRef] [PubMed]

2. Crismon, M.L. Tacrine: First drug approved for Alzheimer's disease. Ann. Pharmacother. 1994, 28, 744-751. [CrossRef] [PubMed]

3. Knapp, M.J.; Knopman, D.S.; Solomon, P.R.; Pendlebury, W.W.; Davis, C.S.; Gracon, S.I.; Apter, J.T.; Lazarus, C.N.; Baker, K.E.; Barnett, M.; et al. A 30-week randomized controlled trial of high-dose tacrine in patients with Alzheimer's disease. JAMA 1994, 271, 985-991. [CrossRef] 
4. $\quad$ Qin, Q.-P.; Wang, S.-L.; Tan, M.-X.; Wang, Z.-F.; Luo, D.-M.; Zou, B.-Q.; Liu, Y.-C.; Yao, P.-F.; Liang, H. Novel tacrine platinum (II) complexes display high anticancer activity via inhibition of telomerase activity, dysfunction of mitochondria, and activation of the p53 signaling pathway. Eur. J. Med. Chem. 2018, 158, 106-122. [CrossRef] [PubMed]

5. Janockova, J.; Plsikova, J.; Koval, J.; Jendželovský, R.; Mikes, J.; Kasparkova, J.; Brabec, V.; Hamulakova, S.; Fedoročko, P.; Kozurkova, M. Tacrine derivatives as dual topoisomerase I and II catalytic inhibitors. Bioorganic Chem. 2015, 59, 168-176. [CrossRef] [PubMed]

6. Sabolová, D.; Kristian, P.; Kozurkova, M. Multifunctional properties of novel tacrine congeners: Cholinesterase inhibition and cytotoxic activity. J. Appl. Toxicol. 2018, 38, 1377-1387. [CrossRef]

7. Janockova, J.; Korábečný, J.; Plsikova, J.; Babkova, K.; Konkolova, E.; Kucerova, D.; Vargova, J.; Koval, J.; Jendzelovsky, R.; Fedorocko, P.; et al. In vitro investigating of anticancer activity of new 7-MEOTA-tacrine heterodimers. J. Enzym. Inhib. Med. Chem. 2019, 34, 877-897. [CrossRef]

8. Correia, A.; Silva, D.; Correia, A.; Vilanova, M.; Gärtner, F.; Vale, N. Study of new therapeutic strategies to combat breast cancer using drug combinations. Biomolecules 2018, 8, 175. [CrossRef]

9. Guidotti, G.; Brambilla, L.; Rossi, D. Cell-penetrating peptides: From basic research to clinics. Trends Pharmacol. Sci. 2017, 38, 406-424. [CrossRef]

10. Copolovici, D.M.; Langel, K.; Eriste, E.; Langel, Ü. Cell-penetrating peptides: Design, synthesis, and applications. ACS Nano 2014, 8, 1972-1994. [CrossRef]

11. Habault, J.; Poyet, J.-L. Recent advances in cell penetrating peptide-based anticancer therapies. Molecules 2019, 24, 927. [CrossRef] [PubMed]

12. Tripathi, P.P.; Arami, H.; Banga, I.; Gupta, J.; Gandhi, S. Cell penetrating peptides in preclinical and clinical cancer diagnosis and therapy. Oncotarget 2018, 9, 37252-37267. [CrossRef]

13. Oehlke, J.; Scheller, A.; Wiesner, B.; Krause, E.; Beyermann, M.; Klauschenz, E.; Melzig, M.; Bienert, M. Cellular uptake of an $\alpha$-helical amphipathic model peptide with the potential to deliver polar compounds into the cell interior non-endocytically. Biochim. Biophys. Acta (BBA)-Biomembr. 1998, 1414, 127-139. [CrossRef]

14. Oehlke, J.; Wallukat, G.; Wolf, Y.; Ehrlich, A.; Wiesner, B.; Berger, H.; Bienert, M. Enhancement of intracellular concentration and biological activity of PNA after conjugation with a cell-penetrating synthetic model peptide. JBIC J. Biol. Inorg. Chem. 2004, 271, 3043-3049. [CrossRef] [PubMed]

15. Scheller, A.; Melzig, M.; Oehlke, J. Induction of caspase-8 in human cells by the extracellular administration of peptides containing a C-terminal SLV sequence. Int. J. Pept. Res. Ther. 2001, 8, 29-34. [CrossRef]

16. Kenien, R.; Shen, W.-C.; Zaro, J.L. Vesicle-to-cytosol transport of disulfide-linked cargo mediated by an amphipathic cellpenetrating peptide. J. Drug Target. 2012, 20, 793-800. [CrossRef]

17. Hällbrink, M.; Florén, A.; Elmquist, A.; Pooga, M.; Bartfai, T.; Langel, Ü. Cargo delivery kinetics of cell-penetrating peptides. Biochim. Biophys. Acta (BBA)-Biomembr. 2001, 1515, 101-109. [CrossRef]

18. Weksler, B.; Romero, I.; Couraud, P.-O. The hCMEC/D3 cell line as a model of the human blood brain barrier. Fluids Barriers CNS 2013, 10, 16. [CrossRef]

19. Martins, C.; Araújo, A.F.; Gomes, M.J.; Fernandes, C.; Nunes, R.; Li, W.; Santos, H.A.; Borges, F.; Sarmento, B. Using microfluidic platforms to develop CNS-targeted polymeric nanoparticles for HIV therapy. Eur. J. Pharm. Biopharm. 2019, 138, 111-124. [CrossRef]

20. Cayero-Otero, M.; Gomes, M.J.; Martins, C.; Álvarez-Fuentes, J.; Fernández-Arévalo, M.; Sarmento, B.; Martín-Banderas, L. In vivo biodistribution of venlafaxine-PLGA nanoparticles for brain delivery: Plain vs. functionalized nanoparticles. Expert Opin. Drug Deliv. 2019, 16, 1413-1427. [CrossRef]

21. Presgraves, S.P.; Ahmed, T.; Borwege, S.; Joyce, J.N. Terminally differentiated SH-SY5Y cells provide a model system for studying neuroprotective effects of dopamine agonists. Neurotox. Res. 2003, 5, 579-598. [CrossRef] [PubMed]

22. Barbosa, D.J.; Capela, J.P.; Silva, R.; Ferreira, L.M.; Branco, P.; Fernandes, E.; Bastos, M.D.L.; Carvalho, F. "Ecstasy"-induced toxicity in SH-SY5Y differentiated cells: Role of hyperthermia and metabolites. Arch. Toxicol. 2013, 88, 515-531. [CrossRef] [PubMed]

23. Barbosa, D.J.; Capela, J.P.; Silva, R.; Vilas-Boas, V.; Ferreira, L.M.; Branco, P.; Fernandes, E.; Bastos, M.D.L.; Carvalho, F. The mixture of "ecstasy" and its metabolites is toxic to human SH-SY5Y differentiated cells at in vivo relevant concentrations. Arch. Toxicol. 2013, 88, 455-473. [CrossRef] [PubMed]

24. Palm-Apergi, C.; Lorents, A.; Padari, K.; Pooga, M. The membrane repair response masks membrane disturbances caused by cell-penetrating peptide uptake. FASEB J. 2008, 23, 214-223. [CrossRef]

25. Saar, K.; Lindgren, M.; Hansen, M.; Eiríksdóttir, E.; Jiang, Y.; Rosenthal-Aizman, K.; Sassian, M.; Langel, Ü. Cell-penetrating peptides: A comparative membrane toxicity study. Anal. Biochem. 2005, 345, 55-65. [CrossRef]

26. Pannecouque, C.; Daelemans, D.; De Clercq, E. Tetrazolium-based colorimetric assay for the detection of HIV replication inhibitors: Revisited 20 years later. Nat. Protoc. 2008, 3, 427-434. [CrossRef]

27. Aguiar, L.; Biosca, A.; Lantero, E.; Gut, J.; Vale, N.; Rosenthal, P.J.; Nogueira, F.; Andreu, D.; Fernàndez-Busquets, X.; Gomes, P. Coupling the antimalarial cell penetrating peptide TP10 to classical antimalarial drugs primaquine and chloroquine produces strongly hemolytic conjugates. Molecules 2019, 24, 4559. [CrossRef] 
28. Ptaszyńska, N.; Gucwa, K.; Olkiewicz, K.; Heldt, M.; Serocki, M.; Stupak, A.; Martynow, D.; Dębowski, D.; Gitlin-Domagalska, A.; Lica, J.; et al. Conjugates of ciprofloxacin and levofloxacin with cell-penetrating peptide exhibit antifungal activity and mammalian cytotoxicity. Int. J. Mol. Sci. 2020, 21, 4696. [CrossRef]

29. Ellman, G.L.; Courtney, K.; Andres, V.; Featherstone, R.M. A new and rapid colorimetric determination of acetylcholinesterase activity. Biochem. Pharmacol. 1961, 7, 88-95. [CrossRef]

30. Mao, F.; Chen, J.; Zhou, Q.; Luo, Z.; Huang, L.; Li, X. Novel tacrine-ebselen hybrids with improved cholinesterase inhibitory, hydrogen peroxide and peroxynitrite scavenging activity. Bioorganic Med. Chem. Lett. 2013, 23, 6737-6742. [CrossRef]

31. Chou, T.-C. Theoretical Basis, Experimental Design, and Computerized Simulation of Synergism and Antagonism in Drug Combination Studies. Pharmacol. Rev. 2006, 58, 621-681. [CrossRef] [PubMed] 